University of Tennessee College of Law

Legal Scholarship Repository: A Service of the Joel A. Katz Law Library

7-31-2018

\title{
Potential Legal Issues in Terminating the ASCAP and BMI Decrees
}

Maurice Stucke

University of Tennessee College of Law

Allen P. Grunes

Brownstein Hyatt Farber Schreck, LLP, agrunes@bhfs.com

Follow this and additional works at: https://ir.law.utk.edu/utklaw_facpubs

\section{Recommended Citation}

Stucke, Maurice and Grunes, Allen P., "Potential Legal Issues in Terminating the ASCAP and BMI Decrees" (2018). UTK Law Faculty Publications. 133.

https://ir.law.utk.edu/utklaw_facpubs/133

This Article is brought to you for free and open access by the Faculty Work at Legal Scholarship Repository: A Service of the Joel A. Katz Law Library. It has been accepted for inclusion in UTK Law Faculty Publications by an authorized administrator of Legal Scholarship Repository: A Service of the Joel A. Katz Law Library. For more information, please contact eliza.boles@utk.edu. 


\section{Potential Legal Issues in Terminating the ASCAP and BMI Consent Decrees}

Allen P. Grunes \& Maurice E. Stucke*

July 31, 2018

* Allen P. Grunes and Maurice E. Stucke are co-founders of The Konkurrenz Group in Washington, D.C., and advise small businesses, Fortune 500 firms, consumer advocacy groups, and governments on issues of competition, privacy, and consumer protection law. They have received financial support from a number of radio broadcasters. 
Allen P. Grunes \& Maurice E. Stucke

Potential Legal Issues in Terminating the ASCAP and BMI Decrees

July 31, 2018

\section{Introduction}

The U.S. Department of Justice's Antitrust Division is currently reviewing nearly 1,300 legacy antitrust judgments to determine which ones should be terminated. ${ }^{1}$ Most of these judgments were entered before 1979, when the Division began using sunset provisions that automatically terminate these judgments, usually 10 years after their entry. ${ }^{2}$ Many of these legacy judgments, the DOJ believes, no longer serve their original purpose of protecting competition. ${ }^{3}$ Besides terminating old decrees, the DOJ recently has clamped down on behavioral remedies and regulatory decrees. ${ }^{4}$

To be sure, many old consent decrees no longer serve any purpose and deserve to be terminated. Some involve companies or even entire industries that no longer exist. Who still cares about the illegal bicycle coaster brake trust of 1913? Yet that decree and others like it remain in effect. Old decrees can be rendered obsolete not only by market changes but by changes in the law. So many old decrees will go out with a whimper, if that.

But two particular consent decrees, if slated for termination, would likely result in a multi-front war. Congress has already weighed in, cautioning the DOJ to not terminate these two decrees without first notifying it. ${ }^{5}$ So what two consent decrees still play such a fundamental role in today's digital economy? The consent decrees with American Society of Composers, Authors, and Publishers ("ASCAP") and Broadcast Music, Inc. ("BMI").

1 The Division recently outlined its process. After identifying a candidate judgment for termination, the Division will seek public comment on the proposed termination and, if appropriate following review of comments, seek to terminate the judgment, typically by filing a motion with the appropriate court. To eliminate the burden on defendants, courts, and the Division of complying with, overseeing, and enforcing outdated judgments, the Division will unilaterally seek to terminate legacy judgments, as appropriate. U.S. Department of Justice, Antitrust Division, Department of Justice's Initiative to Seek Termination of Legacy Antitrust Judgments, 83 FED. REG. 19837 (May 4, 2018),

https://www.justice.gov/atr/page/file/1065011/download.

${ }^{2} I d$.

${ }^{3} I d$.

${ }^{4}$ Assistant Attorney General Makan Delrahim Delivers Keynote Address at American Bar Association's Antitrust, Fall Forum, Washington, DC (November 16, 2017), https://www.justice.gov/opa/speech/assistant-attorney-general-makan-delrahim-deliverskeynote-address-american-bar.

5 Victoria Graham, Music Industry Eyeing Antitrust Cop's Next Move in Licensing, BLOOMBERG BNA (June 13, 2018), https://www.bna.com/music-industry-eyeing-n73014476476/. 
Although the ASCAP and BMI consent decrees were not among the first batch of judgments that the DOJ reviewed for possible termination, both decrees are regulatory in nature and old. Thus, they are potentially on the chopping block. The head of the Antitrust Division, Makan Delrahim, recently sought to assuage this concern somewhat. ${ }^{6}$ Nonetheless, the concern remains. ASCAP's CEO, for example, testified before Congress in 2015 that "regulatory oversight through outdated consent decrees has failed to meet those changes in the marketplace, threatening the future of collective licensing and depriving songwriters and composers of a competitive return on their labor."

This paper addresses some of the likely challenges that the DOJ would face should it seek to terminate the ASCAP and BMI decrees.

In Part I, we provide some background on ASCAP and BMI, the consent decrees, and market structure. In Part II, we discuss how these two decrees have become an important part of the legal scaffolding for licensing music over the past 70 years.

Given the important role the decrees have played in mitigating the antitrust risks from ASCAP and BMI while promoting the efficiencies from collective licensing, Part III examines the legal standard the federal court would likely apply in determining whether to terminate the decrees. One problem is that if the ASCAP and BMI consent decrees were terminated, the duopoly would remain, and licensees and consumers would bear the risk of unduly restrictive anticompetitive practices. A second problem is the difficulties the DOJ would likely face in convincing the court that terminating

\footnotetext{
${ }^{6}$ Assistant Attorney General Makan Delrahim Delivers Remarks at the National Music Publishers Association Annual Meeting (June 13, 2018),

https://www.justice.gov/opa/speech/assistant-attorney-general-makan-delrahim-deliversremarks-national-music-publishers [hereinafter AAG June 13th Speech] ("To be clear, the Antitrust Division has not reached any conclusion about whether the ASCAP and BMI decrees strike the best balance among competition, innovation, and regulation. Congress, moreover, is also paying proper attention to the industry. It is taking a hard look at the Music Modernization Act, and we look forward to seeing that legislation enacted and the results of those changes, which have involved several years of process and input from various interested parties."). 7 Written Statement of Elizabeth Matthews, Chief Executive Officer, American Society of Composers, Authors and Publishers on Performance Rights Organization Consent Decrees, Before the United States Senate Committee on the Judiciary Subcommittee on Antitrust, Competition Policy and Consumer Rights (March 10, 2015), https://www.ascap.com/ /media/files/pdf/press/beth-mathews-written-testimony-for-senatejudiciary-committee.pdf [hereinafter Matthews Testimony].
} 
the decrees would benefit the public, given that it reached the opposite conclusion a couple of years ago. Moreover, the concerns the DOJ heard during its review process from licensees, such as Netflix, Pandora, and religious broadcasters, would undercut the argument that the public would somehow benefit from the decrees' termination.

Part IV examines the interplay between competition and regulation. One assumption is that an antitrust agency's mission to promote competition is in tension with prescriptive government regulation. This is certainly true at times. But at other times, particularly in markets with high transaction costs and dominant players, regulation may be needed to promote competition. So this Part explores how behavioral regulatory decrees, like ones in ASCAP, BMI, and other notable antitrust cases, can actually promote, rather than undermine, competition.

If terminating the decrees will harm, rather than help, competition and consumers, what are the alternatives? Part V offers three potential paths going forward.

\section{Background on ASCAP and BMI Consent Decrees}

\section{a. Brief Background on ASCAP and BMI}

ASCAP is "the oldest and largest performing rights organization ["PRO"] in the United States."8 Its 670,000 songwriters, composers, and music publishers own and run the performing rights organization. ${ }^{9}$ ASCAP is also the "world leader in performance royalties, advocacy and service for music creators." 10

ASCAP licenses over 11.5 million songs and scores to the businesses that play them, then sends the money to its members as royalties. ${ }^{11}$ It uses "cutting edge technology to track, match, process and pay on a trillion performances each year, making [it] one of the most effective and innovative PROs in the world." 12 In 2015, ASCAP represented "almost half of all composers and music publishers in the United

\footnotetext{
8 Id.

9 https://www.ascap.com/ (last visited July 26, 2018).

${ }_{10} I d$.

11 Id.

$12 I d$.
} 
States." 13 As its CEO told Congress in 2015, ASCAP's licenses involved over "500 billion performances made annually by over 700,000 different entities, making it the most efficient PRO in the world." 14

ASCAP's biggest rival is BMI. Founded in 1939, the non-profit performance rights organization holds the public performance rights in over 10 million musical works. ${ }^{15}$ BMI likewise serves as an agent for songwriters and publishers, negotiating rates, issuing licenses, and collecting fees. These original rights-holders-BMI's "affiliates"-grant BMI nonexclusive power to license performance rights to their works. BMI in its 2017 fiscal year generated $\$ 1.130$ billion in revenue, which set a revenue record for the third consecutive year. ${ }^{16} \mathrm{BMI}$ also became in 2017 the world's first performing rights organization to deliver over $\$ 1$ billion to its songwriters, composers and publishers. ${ }^{17}$

\section{b. Brief Background on Market Structure}

Every day, we probably hear music - whether in a restaurant or coffee shop, on the radio, or at a bar or club. ${ }^{18}$ To publicly perform these musical works, businesses must obtain permission from the copyright holders. ${ }^{19}$ The hundreds of thousands of music users mainly rely on ASCAP, BMI, and two smaller performing rights organizations to provide licenses to perform these works. ${ }^{20}$

In the United States, ASCAP and BMI are, by far, the largest performing rights organizations and are responsible for licensing an overwhelming majority of works. ${ }^{21}$

13 Pandora Media, Inc. v. Am. Soc. of Composers, Authors \& Publishers, 785 F.3d 73, 75 (2d Cir. 2015); see also Am. Soc'y of Composers, Authors \& Publishers v. MobiTV, Inc., 681 F.3d 76, 78 (2d Cir. 2012).

14 Matthews Testimony, supra note 7.

15 For more on the background on ASCAP and BMI, see Peter C. DiCola \& Matthew Sag, An Information-Gathering Approach to Copyright Policy, 34 CARDOZO L. REV. 173 (2012).

16 BMI's Timeline Through History, https://www.bmi.com/about/history (last visited July 26, 2018).

17 Id.

18 Statement of the Department of Justice on the Closing of the Antitrust Division's Review of the ASCAP and BMI Consent Decrees (August 4, 2016), https://www.justice.gov/atr/file/882101/download [hereinafter DOJ Closing Statement].

${ }_{19} I d$.

$20 I d$.

$21 \mathrm{Id}$. 
Allen P. Grunes \& Maurice E. Stucke

Potential Legal Issues in Terminating the ASCAP and BMI Decrees

July 31, 2018

As the Second Circuit noted, "Together, ASCAP and BMI license the music performance rights to most domestic copyrighted music in the United States." 22

A third performing rights organization, SESAC, has historically controlled a significant, but much smaller, repertory. ${ }^{23}$ SESAC, as of mid-2018, licensed the public performances of over 400,000 songs on behalf of its 30,000 affiliated songwriters. ${ }^{24}$

In 2013, a fourth performing rights organization, Global Music Rights, entered the market. ${ }^{25}$ Global Music Rights is an "invitation-only" entity with a "small but highprofile" client list; it controls a "considerably smaller" collection of songs than ASCAP or BMI. ${ }^{26}$

Because songwriters can only be members of one performing rights organization, ASCAP and BMI have frequently competed for songwriters. ${ }^{27}$ The performing rights organizations, however, infrequently "compete with each other for licensees, as services such as Pandora typically require a license from all three PROs to operate."28

\section{c. Brief Background on Collective Licensing}

ASCAP and BMI, as well as the smaller performing rights organizations, license music predominantly through "blanket licenses." 29 The performing rights organization pools the copyrights held by their composer, songwriter, and publisher members or affiliates and then collectively license those rights to music users. ${ }^{30} \mathrm{~A}$

22 Broad. Music, Inc. v. DMX Inc., 683 F.3d 32, 36 (2d Cir. 2012).

${ }^{23}$ DOJ Closing Statement, supra note 18.

24 About SESAC, https://www.sesac.com/\#/our-history (last visited July 26, 2018).

25 DOJ Closing Statement, supra note 18.

26 Global Music Rights, About Us, https://globalmusicrights.com/About\#why-gmr (last visited July 26, 2018); DOJ Closing Statement, supra note 18.

${ }^{27}$ Comments of Pandora Media, Inc. in Response to the Department of Justice's Review of the ASCAP and BMI Consent Decrees,

https://www.justice.gov/sites/default/files/atr/legacy/2014/08/27/307973.pdf [hereinafter Pandora Comments] ("While music publishers almost always have catalogs in ASCAP and BMI (and SESAC), the PROs typically do not 'compete' for publishers").

28 Id.; see also Comments of Netflix, Inc. in Response to the Department of Justice's Review of the ASCAP and BMI Consent Decrees (August 6, 2014), https://www.justice.gov/sites/default/files/atr/legacy/2014/08/20/307908.pdf.

${ }_{29}$ United States v. Broad. Music, Inc., 720 F. App’x 14, 15 (2d Cir. 2017) (citing Broad. Music, Inc. v. Prana Hosp., Inc., 158 F. Supp. 3d 184, 189 (S.D.N.Y. 2016)).

30 DOJ Closing Statement, supra note 18. 
blanket license provides access to each organization's entire repertory without regard for what specific songs are used or how often the songs are played. ${ }^{31}$

The collective licensing that has emerged from the ASCAP and BMI consent decrees offer numerous benefits. As ASCAP's CEO told Congress in 2015:

ASCAP negotiates and administers a blanket license for the nondramatic public performance rights in its members' works on a collective basis, monitor music usage by and collect fees from licensees, and distribute royalty payments to its members. A blanket license offered by ASCAP would provide efficiencies for song writers, composers and publishers who would otherwise struggle to individually license or enforce the millions of performances of their works by thousands of individual businesses that publicly perform music, and licensees, who would otherwise find it impossible to clear efficiently the rights for their performances if required to negotiate separately with each individual copyright owner. ${ }^{32}$

Blanket licenses from BMI and ASCAP, as courts have noted, are sufficient to license nearly every domestic copyrighted composition. ${ }^{33}$

But the blanket license is not synonymous with collective licensing. As the Supreme Court stated, ASCAP "may not insist on the blanket license." ${ }_{44}$ ASCAP and BMI, under their consent decrees, must provide licensees a genuine economic choice.

Indeed, Justice Stevens, in his dissent in the $B M I$ case, noted that the licensing market could be more competitive with multiple options. He noted that after the use of blanket licenses in the motion picture industry was discontinued, a competitive market for "synch" rights arose. .35 The "synchronization" right is the right to record a copyrighted song in synchronization with a film or TV show, and is obtained separately from the right to perform the music.

\footnotetext{
31 Id.

32 Matthews Testimony, supra note 7.

${ }^{33}$ United States v. BMI, 720 F. App'x at 15 (citing BMI v. Prana Hosp., 158 F. Supp. 3d at 189).

34 Broad. Music, Inc. v. Columbia Broad. Sys., Inc., 441 U.S. 1, 11 (1979).

35 Id. at 33 (Stevens, J., dissenting).
} 


\section{d. Antitrust Risks of ASCAP and BMI}

Collectively ASCAP and BMI have dominated for years the music licensing business, and continue to do so. As the DOJ told the district court in 2016, "Because ASCAP is a collection of competitors jointly selling at agreed prices and controls a collection of musical works regarded to be essential to many music licensees, it has long raised competitive concerns." ${ }^{36}$

Among the antitrust concerns involving ASCAP and BMI are collusion, exclusionary behavior, and monopoly pricing. The DOJ first investigated allegations of anticompetitive conduct by ASCAP over 90 years ago. ${ }^{37}$ In separate complaints in 1941, the United States charged that the blanket license, which was then the only license offered by ASCAP and BMI, was an illegal restraint of trade and that arbitrary prices were being charged as the result of an illegal copyright pool. ${ }^{38}$ Notably, the United States did not seek to break up these performing rights organizations. Instead it sought to enjoin ASCAP's and BMI's exclusive licensing powers and to require them to offer a different form of licensing. ${ }^{39}$

The cases were settled by consent decrees that imposed tight restrictions on ASCAP's and BMI's operations, including requiring that their blanket license be nonexclusive. ${ }^{40}$ As the Second Circuit noted in 2012, "[s]ettlement of these complaints led to the entry of two separate, but largely similar, consent decrees that continue to substantially control ASCAP and BMI's licensing practices, and minimize the danger of unreasonable activity caused by ASCAP and BMI's market power." 41

\footnotetext{
36 Memorandum in Support of United States' Unopposed Motion to Enter Proposed Settlement Agreement and Order, United States v. Am. Soc'y of Composers, Authors \& Publishers, Case 1:41-cv-01395-DLC-MHD (S.D.N.Y. filed May 12, 2016), https://www.justice.gov/atr/file/851446/download [hereinafter DOJ's Unopposed Motion in ASCAP]. 37 BMI v. Columbia Broad. Sys., 441 U.S. at 11-12.

$38 I d$.

${ }^{39} \mathrm{Id}$.

40 Id.

${ }^{41} B M I$ v. DMX, 683 F.3d at 36 (internal quotes omitted).
} 
The ASCAP and BMI decrees were subsequently modified. ${ }^{42}$ ASCAP's consent decree was last amended in 2001, while BMI's was last amended in 1994. ${ }^{43}$ As the Supreme Court noted, the decrees can evolve and be updated. ${ }^{44}$

At the request of ASCAP and BMI, the DOJ, in 2014, opened an inquiry into the operation and effectiveness of the consent decrees. ${ }^{45}$ The DOJ "solicited two rounds of public comments regarding the consent decrees and met with dozens of industry stakeholders." 46 At the end of the process, "[a]fter carefully considering the information obtained during its investigation," the DOJ reiterated the benefits of the decrees: "In the decades since the ASCAP and BMI consent decrees were entered, industry participants have benefited from the 'unplanned, rapid and indemnified access' to the vast repertories of songs that each PRO's blanket licenses make available." 47 Thus, the DOJ concluded that since "the industry has developed in the context of, and in reliance on, these consent decrees ... they therefore should remain in place." ${ }^{48}$

\section{The ASCAP And BMI Consent Decrees Are an Important Part of the Legal Scaffolding for Licensing Music}

As the Supreme Court observed in 1979, and remains true today, the decrees are "a fact of economic and legal life in this industry." 49 The antitrust consent decrees enable users and artists to reap the efficiencies from each organization's collective

\footnotetext{
${ }^{42}$ BMI v. Columbia Broad. Sys., 441 U.S. at 10-11 (1979) (noting that following complaints relating to the television industry, successful private litigation against ASCAP by movie theaters, and a Government challenge to ASCAP's arrangements with similar foreign organizations, the 1941 decree was reopened and extensively amended in 1950).

43 Radio Music License Comm., Inc. v. SESAC Inc., No. 12-CV-5807, 2013 WL 12114098, at *3 (E.D. Pa. Dec. 23, 2013), report and recommendation adopted as modified, No. 12-CV-5807, 2014 WL 12617437 (E.D. Pa. Feb. 20, 2014).

44 BMI v. Columbia Broad. Sys., 441 U.S. at 13 ("But it cannot be ignored that the Federal Executive and Judiciary have carefully scrutinized ASCAP and the challenged conduct, have imposed restrictions on various of ASCAP's practices, and, by the terms of the decree, stand ready to provide further consideration, supervision, and perhaps invalidation of asserted anticompetitive practices.").

45 DOJ Closing Statement, supra note 18.

$46 I d$.

${ }^{47}$ Id. (quoting BMI v. Columbia Broad. Sys., 441 U.S. at 20).

$48 I d$.

${ }^{49}$ BMI v. Columbia Broad. Sys., 441 U.S. at 13.
} 
licensing, while reducing the anticompetitive risks from these two dominant performing rights organizations.

Licensees typically cannot play ASCAP and BMI off of each other. Since together they control over 90 percent of compositions, and each of them is so large as to be considered essential, licensees generally need licenses from both PROs. Thus, ASCAP and BMI, absent the decrees, could exercise significant market power.

The decrees, however, have several important safeguards. Under the decrees, members may grant ASCAP and BMI only nonexclusive rights to license their works for public performance. ${ }^{50}$ Members, therefore, retain the rights individually to license public performances, along with the rights to license the use of their compositions for other purposes. ${ }^{51}$

Users can obtain a blanket license upon request (the effective compulsory license provisions). But neither ASCAP nor BMI can insist on the blanket license. They must offer the applicant a genuine economic choice between a per-program license and the more common blanket license. ${ }^{52}$

If a licensee cannot agree on a fee in its negotiations with either ASCAP or BMI within 60 days, the applicant may apply to the District Court for a determination of a reasonable fee, with ASCAP or BMI having the burden of proving reasonableness. ${ }^{53}$ Both the ASCAP and BMI consent decrees include a "rate court" mechanism under which the United States District Court for the Southern District of New York has jurisdiction to determine reasonable license fees when the parties to a licensing transaction are unable to reach agreement. ${ }^{54}$

Consequently, as the Florida Restaurant and Lodging Association commented to DOJ, "while any system of delivery, especially over time, will require modifications, the Consent Decrees under review have by and large provided several intertwined industries, from the creator of the product to its delivery to the ultimate end-user, a stable and predictable platform in which to conduct business." ${ }^{55}$ In deciding to

\footnotetext{
$50 I d$. at $11-12$.

$51 \mathrm{Id}$.

$52 I d$.

$53 I d$.

54 BMI v. DMX, 683 F.3d at 37.

55 Letter from Florida Restaurant and Lodging Association to U.S. Dep't of Justice, Antitrust Div., Lit. III Section, dated Aug. 1, 2014, https://www.justice.gov/sites/default/files/atr/legacy/2014/09/04/307675.pdf.
} 
terminate these decrees, the DOJ and court would have to consider this economic reality.

\section{Legal Standard for Terminating a Consent Decree}

Today many antitrust consent decrees have a sunset provision, generally ten years, whereupon, absent extension, they automatically terminate. Earlier consent decrees, like the BMI and ASCAP decree, lack such a provision. So one key issue is the legal standard to assess whether an antitrust consent decree should be terminated.

In seeking to terminate other decrees recently, the DOJ told the district court that given "its jurisdiction and its authority, the Court may terminate each judgment for any reason that justifies relief, including that the judgments no longer serve their original purpose of protecting competition."56 The DOJ also cited the following factors as to why the decrees should be terminated:

- their age suggested that they no longer protect competition,

- all the terms of the judgment were satisfied (i.e., identifying one judgment where defendants were required years ago to divest certain businesses shortly after they merged),

- defendants likely no longer exist (i.e., companies have gone out of business),

- the terms of the judgment merely prohibit that which the antitrust laws already prohibit (namely price fixing, customer allocations, or group boycotts for which defendants who engage in this type of behavior face the possibility of imprisonment, significant criminal fines, and treble damages in private followon litigation thereby making such antitrust violations unlikely to occur), or

- changed market conditions likely have rendered specific judgments ineffectual (in that these judgments concern products or markets that likely no longer exist, no longer are substantial in size, or now face different competitive forces). .57

As there was no opposition to the terminations of these decrees, the district court may grant the DOJ's motion to terminate.

\footnotetext{
56 Memorandum in Support of the Motion of the United States to Terminate Legacy Antitrust Judgments at 5-6, filed in United States v. American Amusement Ticket Manufacturers Association, et al. (D.D.C. filed July 9, 2018), https://www.justice.gov/opa/pressrelease/file/1078981/download.

${ }^{57} \mathrm{Id}$. at 5-6.
} 
But a different court would not necessarily apply the DOJ's criteria in a contested proceeding. In terminating the ASCAP and BMI decrees, the DOJ would need to go to the U.S. District Court for the Southern District of New York. That court would likely apply the standard that the Second Circuit adopted in 1995 for terminating an antitrust consent decree.

In United States v. Eastman Kodak Co., Eastman Kodak Co. sought to terminate two antitrust consent decrees. ${ }^{58}$ The 1921 decree, which was entered after the district court found that Kodak had monopolized the sale of cameras and photographic supplies, imposed various restrictions on Kodak's business practices, including preventing Kodak from selling "private label" film.59 The 1954 decree prevented Kodak from selling its film in a "bundle" with its photofinishing services. ${ }^{60}$ After a nine-day evidentiary hearing, the district court granted Kodak's motion to terminate both decrees. The United States appealed. ${ }^{61}$

One disputed issue on appeal was the legal standard to terminate an antitrust consent decree. In exercising its equitable discretion to terminate the 1921 and 1954 Decrees, the district court required Kodak to prove that: (1) it no longer possesses market power over film and photofinishing, and therefore that the primary purposes of the decrees-the elimination of monopoly and unduly restrictive practices-have been achieved; and (2) termination of the consent decrees would benefit consumers. The Second Circuit affirmed this standard. ${ }^{62}$

\section{a. Whether BMI and ASCAP Still Possess Market Power Over Music Licensing}

The first issue under the Kodak standard is whether BMI and ASCAP still possess market power over music licensing. If not, then the primary purposes of the decreesthe elimination of monopoly and unduly restrictive practices-were achieved.

\footnotetext{
5863 F.3d 95, 101 (2d Cir. 1995).

${ }^{59} \mathrm{Id}$. at 97 . Private label film is marketed under a brand name other than Kodak's, typically that of a retail outlet.

$60 I d$.

${ }^{61} I d$. (concluding that, under the legal standards established by Rufo v. Inmates of Suffolk Cty. Jail, 502 U.S. 367 (1992) and United States v. United Shoe Mach. Corp., 391 U.S. 244 (1968), the district court's resolution of these issues in Kodak's favor provided a proper basis for the court's decision to terminate the consent decrees).

62 Id. at 102.
} 
ASCAP and BMI, however, still possess significant market power over music licensing. The two smaller performing rights organizations license far fewer songs. SESAC, as of mid-2018, for example, licensed the public performances of 400,000+ songs, which is miniscule compared to ASCAP's 11.5 million songs and BMI's 10+ million songs.

One potential check on ASCAP's and BMI's market power, the DOJ acknowledged, is that the consent decrees allow the individual rights holders to the songs to directly license with businesses and other users. ${ }^{63}$

First, this check comes from the protections afforded by the consent decrees, and not the competitive pressure from rivals.

Second, the National Religious Broadcasters Music License Committee noted in its comments to the DOJ how the music publishing industry is "highly concentrated" and "three major publishers now control the vast majority of musical works."64

Even if the decrees were terminated, and the rights holders could negotiate independently, this still would be a weak check on ASCAP's and BMI's market power. Negotiations can be time-consuming and costly. So BMI and ASCAP could factor these transaction costs in determining how much to raise their license fees.

As the DOJ told the court in 2016, "Courts have long recognized that ASCAP indisputably exercises market power." ${ }^{65}$ Likewise, the Second Circuit noted in 2012,

63 Memorandum of the United States on Decree Construction Issues, filed in BMI v. DMX, 08 Civ. 216 (LLS) (S.D.N.Y. filed April 13, 2010), https://www.justice.gov/atr/case-

document/memorandum-united-states-decree-construction-issues-relating-united-states-v ("direct licensing between rights holders and users establishes the most effective market-based constraint on BMI's pricing because it places an upper limit on the price that BMI can charge for the blanket license. If the BMI collective charged more for a blanket license than users would pay if they licensed directly, users would forego a blanket license from BMI.").

${ }^{64}$ Comments of the National Religious Broadcasters Music License Committee In re ASCAP and BMI Consent Decree Review (August 6, 2014), at 2-3, https://www.justice.gov/sites/default/files/atr/legacy/2014/08/14/307806.pdf [hereinafter National Religious Broadcasters' Comments].

65 Petition of the United States for an Order to Show Cause Why Respondent American Society of Composers, Authors and Publishers Should Not Be Found in Civil Contempt, filed in United States v. Am. Soc'y of Composers, Authors \& Publishers, Supplemental to Case No. 41-1395 
because "of concerns that ASCAP's size grants it monopoly power in the performancerights market, it is subject to a judicially-administered consent decree." 66 The Second Circuit made the same finding for BMI. ${ }^{67}$ Others during the DOJ's review of the consent decree raised concern over ASCAP's and BMI's dominance. ${ }^{68}$ Netflix, for example, told the DOJ how "the Consent Decrees remain vital to constrain the market power of ASCAP and BMI." 69

The fact that ASCAP and BMI still dominate musical licensing does not represent a failure of the consent decrees. The consent decrees never sought structural relief to eliminate this duopoly. Instead, the aim was to allow ASCAP and BMI to exist in order to obtain the significant efficiencies in having these organizations offer nonexclusive collective licensing, but to prevent unduly restrictive practices by the two organizations. As the DOJ noted in 2015 when challenging ASCAP's exclusive dealing, the consent decree "imposes a number of restrictions on ASCAP designed to prevent its anticompetitive exercise of market power." 0

Consequently, if the ASCAP and BMI consent decrees were eliminated, the duopoly would remain, but there would be no viable check to deter either of them from engaging in unduly restrictive practices. ASCAP and BMI, if unconstrained, would

(DLC) (S.D.N.Y. filed May 12, 2016), https://www.justice.gov/atr/file/850926/download (citing In re THP Capstar Acquisition Corp., 756 F. Supp. 2d 516, 541 (S.D.N.Y. 2010)).

66 Am. Soc'y of Composers, Authors \& Publishers v. MobiTV, Incorporation, 681 F.3d 76, 79 (2d Cir. 2012); see also In re THP Capstar Acquisition Corp., 756 F. Supp. 2d at 541 (ASCAP consent decree "is an antitrust consent decree providing a mechanism for the setting of reasonable license fees in a unique market in which ASCAP indisputably exercises market power"), aff'd sub nom. Broad. Music, Inc. v. DMX Inc., 683 F.3d 32 (2d Cir. 2012).

67 MobiTV, 681 F.3d at 88 (BMI "represents most of the remaining composers in the American market" so it too "operates under a consent decree similar to ASCAP's").

${ }^{68}$ National Religious Broadcasters' Comments, supra note 64 ("The market for music performance rights is not competitive and the Consent Decrees remain critical to restraining anticompetitive behavior by ASCAP and BMI."); Netflix Comments, supra note 28 ("The extraordinary market power and leverage created by the aggregation of copyrights and blanket licensing practices of ASCAP and BMI are beyond dispute by now.").

69 Netflix Comments, supra note 28.

70 U.S. Dep't of Justice, Press Release, Justice Department Settles Civil Contempt Claim Against ASCAP for Entering Into 150 Exclusive Contracts with Songwriters and Music Publishers (May 12, 2016), https://www.justice.gov/opa/pr/justice-department-settles-civilcontempt-claim-against-ascap-entering-150-exclusive [hereinafter DOJ May 12th Press Release]. 
have the power and incentive to raise price above competitive levels. ${ }^{71}$ They would also have the power and incentive to engage in other anticompetitive practices. For example, they could refuse to license, or include anticompetitive terms in their licenses. As the district court noted in one rate dispute case, "While ASCAP may be unwilling to offer a blanket license with a carve-out for a direct licensing program, the terms of [the consent decree], the decisions interpreting and applying [the consent decree], and the record evidence from this trial each indicate that such a license is appropriate and justified here." ${ }^{\prime 2}$

As ASCAP and BMI continue to have market power, it is unlikely that the DOJ could satisfy the first prong.

\section{b. Whether Termination of the Consent Decrees Would Benefit Consumers}

Even if one put aside the first prong, the United States would also have to show that terminating the consent decrees would benefit consumers. Here the DOJ would likely have a hard time convincing the court, given that it concluded only two years ago that consumers have benefitted and continue to benefit from the existence of decrees. Consumers benefit from the output of musical performance that is enabled by the decrees.

Industry participants and consumer groups likely would raise serious concerns if the DOJ unilaterally decided to terminate the decrees. ${ }^{73}$ As a Public Knowledge participant told the DOJ in its April 26, 2018 Roundtable on Antitrust Consent Decrees:

The issue is that in the absence of a consent decree and in the absence of any kind of oversight, we have seen examples of anticompetitive behavior that the PROs have engaged in. ... But because of this tendency towards collective negotiation and blanket licensing, which is fundamentally an efficiency for all players involved really, it does raise certain behavioral

\footnotetext{
71 MobiTV, 681 F.3d at 82 ("rate-setting court must take into account the fact that ASCAP, as a monopolist, exercises market-distorting power in negotiations for the use of its music"). 72 In re THP Capstar Acquisition Corp., 756 F. Supp. $2 d$ at 541.

73 See, e.g., Pandora Comments, supra note 27 (noting that "while other decrees may be outdated, these decrees are relevant and needed more than ever in light of increasing market concentration in the music publishing industry"); National Religious Broadcasters' Comments, supra note 64 ("The only protection that users have against ASCAP's and BMI's monopoly power is the protection provided by the Consent Decrees.").
} 
incentives for these groups to collude or to boycott or to [attempt] things like partial withdrawal where they said despite the fact that we were required to treat all comers equally, we would like to be able to discriminate based on technology. And so these kinds of things naturally arise. And we've seen arise over and over and over again, including in, frankly, SESAC, which is not subject to a consent decree. It has a substantially smaller catalog portfolio than BMI and ASCAP, which I believe had together over 90\% of most of the works in circulation. But we've seen SESAC do sort of similar-the highly legal term I guess would be shenanigans regarding collusion with publishers. ${ }^{74}$

Generally, the decrees, in lowering transaction costs, have expanded output. But the concern would be that an unregulated BMI and ASCAP could engage in anticompetitive behavior that would leave businesses and music listeners worse off.

\section{c. Antitrust Litigation Is Not a Surrogate for the Protections Afforded Under the Consent Decrees}

One potential rejoinder is that ASCAP and BMI would still be subject to the Sherman Act. Thus, the fear of treble damages would deter them from acting badly. While the threat of antitrust prosecution could chill particularly egregious anticompetitive behavior, the threat of antitrust lawsuits could not effectively replace the protections afforded in the ASCAP and BMI consent decrees.

First, the DOJ is powerless to challenge under the Sherman Act a monopoly charging higher prices. Thus, ASCAP and BMI would no longer have to fear their supracompetitive pricing being challenged under the decrees' Rate Courts. They could charge, like some pharmaceuticals, monopoly prices, without fear of antitrust liability.

Second, even for unduly restrictive practices prohibited by the Sherman Act, the time, expense, and uncertainty in bringing an antitrust case under section 1 or 2 of the Sherman Act would significantly diminish the deterrence value from any threatened

${ }^{74}$ U.S. Dep't of Justice, Antitrust Div., Public Roundtable Discussion Series on Regulation \& Antitrust Law, Session Two: Antitrust Consent Decrees: Transcript Part One (April 26, 2018), https://www.justice.gov/atr/page/file/1067496/download. 
litigation. ${ }^{75}$ Some smaller bars and restaurants, for example, have noted that disputing "a $\$ 500$ or even $\$ 1,000$ fee discrepancy" in the Rate Courts "can involve significant legal and travel costs to a licensee, a fact that does not escape the PROs as they determine rates." 76 Thus, if small establishments find it difficult to challenge ASCAP's or BMI's fees, it is unlikely that they could undertake individually or collectively a rule of reason case that would drag on for years, and cost of millions of dollars with economic experts, discovery and litigation fees.

Third, further undermining the licensees' incentive is the low odds in prevailing under antitrust's rule of reason standard. For example, an unconstrained BMI or ASCAP could effectively refuse to deal and cripple a business.

The head of the Antitrust Division recently noted the enforcement gap between the United States and Europe: "European competition law still imposes a 'special duty' on dominant market players, while we in the U.S. do not believe any such duty exists." 77 This is a bit of an overstatement. Earlier courts interpreting the Sherman Act imposed special duties on monopolies. ${ }^{78}$ But the Supreme Court has limited the duty of a monopoly to deal with its rivals. ${ }^{79}$ Thus, an unregulated BMI and ASCAP could refuse to license in ways that reduce competition and overall welfare. As the District Court overseeing the consent decree noted, the consent decrees prevent this anticompetitive scenario. ${ }^{80}$

75 See, e.g., Maurice E. Stucke, Does the Rule of Reason Violate the Rule of Law?, 42 U.C. DAVIS L. REV. 1375 (2009).

76 Letter from American Beverage Licensees to the U.S. Dep't of Justice, Antitrust Div., dated Aug. 5, 2014, https://www.justice.gov/sites/default/files/atr/legacy/2014/08/13/307662.pdf; see also Letter from Florida Restaurant and Lodging Association, supra note 55.

77 Makan Delrahim, Assistant Attorney Gen., Dep’t of Justice, Good Times, Bad Times, Trust Will Take Us Far: Competition Enforcement and the Relationship Between Washington and Brussels (Feb. 21, 2018), https://www.justice.gov/opa/speech/assistant-attorney-general-makandelrahim-delivers-remarks-college-europe-brussels.

78 See, e.g., Otter Tail Power Co. v. United States, 410 U.S. 366, 373 (1973) (monopoly's consistent refusals to wholesale or wheel power to its municipal customers constituted illegal monopolization).

79 Verizon Commc'ns Inc. v. Law Offices of Curtis V. Trinko, LLP, 540 U.S. 398, 409 (2004) (noting that the duty to deal imposed in Aspen Skiing Co. v. Aspen Highlands Skiing Corp., 472 U.S. 585 (1985) was at or near the outer boundary of liability under $\S 2$ of the Sherman Act). 80 Broad. Music, Inc. v. Pandora Media, Inc., No. 13 CIV. 4037 LLS, 2013 WL 6697788, at *5 (S.D.N.Y. Dec. 19, 2013) ("BMI and the intervenors argue that nothing in the BMI Consent Decree prevents BMI from agreeing not to serve particular customers. That puts matters backwards. Nothing in the Consent Decree settling this antitrust case can be read to allow one 
An unconstrained ASCAP and BMI could also engage in anticompetitive exclusive dealing, which would be harder for the DOJ to monitor and deter. Beginning in approximately 2008, ASCAP inserted language into many loan side letters and advance and guarantee agreements that ASCAP would be the exclusive licensor of the members' rights. ${ }^{81}$ All told, ASCAP entered into approximately 150 contracts with songwriter and publisher members that made ASCAP the exclusive licensor of their performance right. ${ }^{82}$ This exclusivity clearly violated the ASCAP consent decree. As the DOJ told the court, the consent decree's non-exclusivity provisions "are at the heart of the relief" that the decree provides. ${ }^{83}$ In 2015, ASCAP settled, promising, among other things, "not to enter into further exclusive contracts and agreed to reform its licensing practices to remove music publishers from overseeing ASCAP's licensing." ${ }^{4}$

Despite the clear provisions in a court order prohibiting ASCAP from interfering with its members' ability to directly license their songs, ASCAP, nonetheless, violated the decree for seven years. If the consent decree did not deter this anticompetitive behavior, it is hard to imagine how the threat of an antitrust suit, in a post-decree world, would deter ASCAP and BMI. Especially when antitrust plaintiffs often lose exclusive dealing cases..$^{85}$

The DOJ, in bringing the civil contempt case against ASCAP and seeking a fine, sought to send "an important message to ASCAP and others subject to antitrust consent decrees that they must abide by the terms of the decrees or face significant

with BMI's market power to refuse to deal with certain of its applicants. The copyright law necessarily gives that privilege to the intervenors, but BMI cannot combine with them by holding in its repertory compositions that come with an invitation to a boycott attached."); see also In re Pandora Media, Inc., No. 12 CIV. 8035 DLC, 2013 WL 5211927, at *8 (S.D.N.Y. Sept. 17, 2013), aff'd sub nom. Pandora Media, Inc. v. Am. Soc. of Composers, Authors \& Publishers, 785 F.3d 73 (2d Cir. 2015) (ASCAP decree denies "ASCAP the power to refuse to grant public performance rights to songs to particular users while, at the same time, retaining the songs in question in its repertory").

81 DOJ's Unopposed Motion in ASCAP, supra note 36.

$82 I d$.

$83 \mathrm{Id}$.

84 DOJ May 12th Press Release, supra note 70.

85 See, e.g., Morales-Villalobos v. Garcia-Llorens, 316 F.3d 51, 55 (1st Cir. 2003) ("many of these antitrust cases brought by excluded medical care providers are ultimately decided against plaintiffs, usually after summary judgment or trial"). 
consequences." 86 With the decree gone, that deterrence would also likely disappear. All that would remain would be a costly, time-consuming rule of reason case.

\section{Anti-regulatory Arguments Are Inapplicable Here}

But the issue here goes beyond whether or not the ASCAP and BMI decrees should be terminated. The issue goes to the relationship between competition and regulation. In a recent speech, Makan Delrahim said, "The core mission of the Antitrust Division is to protect and preserve this kind of competition. At its most fundamental level, our mission is in tension with prescriptive government regulation." 87

That is often the case with anti-competitive regulatory restraints that protect an industry, at the expense of competition and consumers. One classic example involves real estate. ${ }^{88}$ Some states significantly limit the ability of licensed real estate brokers to compete. In this topsy-turvy regulatory world, buyers' brokers, for example, get in trouble for offering home buyers refunds on commissions. Here the tension between antitrust and these anticompetitive state regulations is evident.

Regulations can limit economic growth. Weak antitrust enforcement also may limit growth, because it tends to lock in the companies that are currently the winners and make it hard for them to be toppled. So we understand the impetus toward less regulation and strong antitrust enforcement - a view with sound historical roots.

However, in markets with significant transaction costs, as is the case here, some degree of regulation may be needed. The economist Douglass North, in a speech accepting the Nobel Prize, made this point:

Institutions are the humanly devised constraints that structure human interaction. They are made up of formal constraints (rules, laws, constitutions), informal constraints (norms of behavior, conventions, and self imposed codes of conduct), and their enforcement characteristics. Together they define the incentive structure of societies and specifically economies. Institutions and the technology employed determine the transaction and transformation costs that add up to the costs of

86 DOJ May 12th Press Release, supra note 70.

87 AAG June 13th Speech, supra note 6.

88 U.S. Dep't of Justice, Antitrust Div., Competition and Real Estate (last visited July 26, 2018), https://www.justice.gov/atr/competition-and-real-estate-0. 
production. It was Ronald Coase (1960) who made the crucial connection between institutions, transaction costs, and neo-classical theory. The neoclassical result of efficient markets only obtains when it is costless to transact. Only under the conditions of costless bargaining will the actors reach the solution that maximizes aggregate income regardless of the institutional arrangements. When it is costly to transact then institutions matter. ${ }^{89}$

No one disputes that the transaction costs for policing IP rights and licensing would be astronomical in the music industry absent collective licensing. Imagine if thousands of users, if they wanted to use many, if not all, of the tens of millions of compositions, had to identify and then negotiate with the tens of thousands of copyright owners. Then add the costs in monitoring who was licensed to use the music and who wasn't. Everyone-listeners, businesses that license the music, and the artists-would be worse off in this world.

Not surprisingly, Assistant Attorney General Delrahim recently praised the blanket license as a "crucial innovation." 90 But the pro-competitive features of the blanket license did not materialize out of ether. The pro-competitive benefits arose from a critical regulatory institution, namely the courts and the DOJ in enforcing the ASCAP and BMI consent decrees.

Here regulations, rather than undermining competition, provide the needed scaffolding to ensure that we get the transformative benefits of collective licensing, while mitigating the anticompetitive risks from this duopoly. Thus, given the high transaction costs of music licensing and ASCAP's and BMI's ability to exercise significant market power, legal institutions (like the BMI and ASCAP consent decrees) matter. A regulatory framework is needed to yield the efficiencies from the one-stop-shopping from the PROs, while curbing the abuses of market power.

And ASCAP and BMI are not unique. One early antitrust case provides another example of how a regulatory decree can promote competition. In United States $v$. Terminal R.R. Ass'n of St. Louis, all the railroads coming into St. Louis had three competing options to cross the Mississippi River. ${ }^{91}$ However, Jay Gould and 14

\footnotetext{
89 Douglass C. North, Lecture to the Memory of Alfred Nobel, Economic Performance through Time (December 9, 1993), https://www.nobelprize.org/nobel_prizes/economicsciences/laureates/1993/north-lecture.html.

90 AAG June 13th Speech, supra note 6.

91224 U.S. 383, 391-94 (1912).
} 
railroad companies formed a joint venture to acquire the two bridges and Wiggins Ferry Company, and thereby control access across the Mississippi River in St. Louis. Moreover, the area's topography and the cost of constructing and maintaining a railroad bridge made it impracticable for every railroad desiring to enter or pass through the city to have its own bridge. As a result, it was, as a practical matter, impossible for any railroad company to pass through, or even enter St. Louis, without using the joint venture's facilities.

The government sought to break up the joint venture, which was perhaps justifiable given that it purchased pre-existing bridges rather than building them. The Supreme Court left open this option. ${ }^{92}$ But the Court chose a regulatory decree. The joint venture had to admit members on reasonable and non-discriminatory terms. And any other railroad that did not want to become a member of the joint venture could still use the terminal facilities upon such "just and reasonable" terms. And like ASCAP and BMI, any disagreement over a fair and reasonable fee would be submitted to the district court.

We see this same approach in the 1945 case, Associated Press v. United States. ${ }^{93}$ Like ASCAP and BMI, the Associated Press had many members (over 1,200 newspapers at that time). And the joint venture, like BMI and ASCAP, significantly lowered its members' costs. Associated Press lowered its members' costs in reporting news. Instead of each newspaper, for example, sending a sports reporter to cover the University of Tennessee-Florida football game, each newspaper could republish the story by the local Knoxville newspaper who was a member of AP. ASCAP and BMI can lower its members' costs in monitoring the use of their songs, and collecting royalties.

Because the association itself offered significant pro-competitive efficiencies, the United States did not seek to dismantle AP. Instead, the government sought a regulatory decree to deter certain anticompetitive practices against rival newspapers, with the court's ability to modify the decree to prevent other discriminatory restraints against non-member newspapers.

As these cases reflect, competition, in a world with high transaction costs, needs legal institutions - whether they are laws, regulations, or regulatory consent decrees. This

92 Id. at $412-13$.

93326 U.S. 1 (1945). 
is especially true where one seeks to gain the pro-competitive benefits from dominant companies, like a blanket license, while mitigating the anti-competitive risks that these entities pose. So the choice isn't whether the BMI and ASCAP decree should be terminated. Rather, as the next Part discusses, what would be the optimal regulatory framework?

\section{Paths Going Forward}

As we have seen, simply terminating the BMI and ASCAP decrees is, by far, the worst option. Licensees would be left with a duopoly with little, if any, protections. The likely result would be supra-competitive prices, less output, and higher transaction costs.

Nor is breaking up BMI and ASCAP a feasible or desirable option. The transaction costs in licensing would likely increase. As the head of the ABA Antitrust Section recently told the DOJ, "But in the absence of [Congressional] action, I think continuation of those decrees, perhaps with some modifications, is essential, because you certainly you don't want to break up BMI and ASCAP. The efficiencies of two stop shopping for broadcasters are really too great to provide." 94

Keeping BMI and ASCAP, but eliminating collective licensing, is not a feasible option for similar reasons. A key benefit would disappear. As ASCAP's CEO told Congress in 2015, "If not for PRO collective licensing, the billions of performances made by digital music services such as Pandora, Spotify and Apple's iTunes Radio would require clearance on a copyright-owner-by-copyright-owner basis - exactly the problem faced by ASCAP's founders years ago, but on a magnitude far greater."95

Instead, there are at least three viable options to promote allocative efficiency, while deterring monopolistic abuses:

\section{a. Modification of Current Decrees}

After its recent and extensive inquiry into the operation and effectiveness of the ASCAP and BMI consent decrees, the DOJ was fairly positive about the decrees'

94 DOJ Public Roundtable Discussion Series on Regulation \& Antitrust Law, supra note 74.

95 Matthews Testimony, supra note 7. 
effectiveness: "Although stakeholders on all sides have raised some concerns with the status quo, the Division's investigation confirmed that the current system has well served music creators and music users for decades and should remain intact." 96 As the head of the ABA Antitrust Section recently told the DOJ, "There's no guarantee that you're going to get a better public policy outcome from a new case than by tweaking the decree, or better yet, as I've mentioned, getting a congressional enactment. So in this particular case-I know we've focused on it to the exclusion of pretty much everything else-I think this one sort of has its own glue."97

No doubt the consent decrees are far from perfect. ASCAP in 2015, for example, proposed a number of modifications to its consent decree, including (i) expediting the rate-setting process (using arbitration rather than federal courts), ${ }^{98}$ (ii) licensing multiple rights (namely permitting ASCAP to license mechanical, synchronization and print rights in addition to public performance rights when requested to do so by its members), and (iii) permitting limited grants of rights (permitting ASCAP to accept partial grants of rights from copyright holders). ${ }^{99}$

As to the first point, a trade association of smaller bars and restaurants have advocated arbitration. ${ }^{100}$ Other licensees, however, disagreed, pointing to the district court's expertise, ${ }^{101}$ and the informational asymmetries between the PROs and

96 DOJ Closing Statement, supra note 18.

${ }^{97}$ DOJ Public Roundtable Discussion Series on Regulation \& Antitrust Law, supra note 74. 98 Matthews Testimony, supra note 7.

99 Id.

100 American Beverage Licensees Letter, supra note 76; see also Letter from Florida Restaurant and Lodging Association, supra note 55.

101 Public Comments Submitted to the United States by Fox News Network, LLC Concerning Review of Antitrust Consent Decrees in the Above-Captioned Matters, filed in United States v. Am. Soc. of Composers, Authors \& Publishers et al., Civ. Action No. 41-1395 (S.D.N.Y. filed August 6, 2014), https://www.justice.gov/sites/default/files/atr/legacy/2014/08/13/307811.pdf ("The existing rate court has developed extensive expertise in the field, and has provided fairness, transparency and consistency to copyright owners and music users for many decades. The rate court mechanism has thus benefitted competition and has served the public interest. These benefits would be difficult or impossible to achieve under arbitration."); Letter from National Public Radio, Inc. to U.S. Dep’t of Justice, Antitrust Div., Lit. III Section, dated Aug. 6, 2014, https://www.justice.gov/sites/default/files/atr/legacy/2014/08/13/307970.pdf; National Religious Broadcasters' Comments, supra note 64. 
licensees. ${ }^{102}$ Regardless, reducing the costs to resolve disputes appears to have support from both the PROs and licensees. ${ }^{103}$

With respect to the second point, licensing multiple rights, this could potentially lower transaction costs, thereby benefitting purchasers. ASCAP currently can license the right of public performance, which is one of several exclusive rights provided to copyright holders of musical compositions. But ASCAP cannot include in its blanket license mechanical rights (the right to reproduce and distribute musical works as phonorecords); synchronization rights (the right to use a recording of a musical work in timed relation with visual images, for example as part of a motion picture or television program); and print rights (the right to print or display a composition's lyrics). ${ }^{104}$ To obtain licenses for mechanical and synchronization rights, one typically has to negotiate with the music publishers or their agents (such as the Harry Fox Agency). ${ }^{105}$ As BMI and other PROs in theory can license these other rights, ASCAP seeks to do so as well.

But as Netflix pointed out, "one of the additional rights which the PROs apparently wish to be able to license - musical work synchronization rights - are currently licensed in a far more price-competitive marketplace than the one that exists for the licensing of composition performance rights." 106 So, Netflix questions permitting ASCAP and BMI "to augment their ability to license in a marketplace that is currently functioning in a price-competitive manner."107

Moreover, Congress is currently considering under its proposed Music Modernization Act to vest complete authority for mechanical licensing in one newly-created body. So the PROs would be precluded from bundling performance and mechanical rights.

\footnotetext{
102 Netflix Comments, supra note 28.

103 Public Comments of the American Society of Composers, Authors and Publishers Regarding Review of the ASCAP and BMI Consent Decrees (August 6, 2014), https://www.justice.gov/sites/default/files/atr/legacy/2014/08/14/307803.pdf (noting that "Rate Court proceedings under the Consent Decree have become extremely time-consuming and laborintensive, costing the parties millions in litigation expenses").

$104 \mathrm{Id}$.

$105 \mathrm{Id}$.

106 Netflix Comments, supra note 28.

107 Id.
} 
As to the third point, the DOJ recently lost to BMI on the issue of whether its consent decree requires BMI to issue blanket licenses only on a "full-work" basis, or whether they also allow the PROs to license songs on a "fractional" basis."108 The DOJ concluded that the consent decree required the PRO to offer only "full-work" licenses because "only full-work licensing can yield the substantial procompetitive benefits associated with blanket licenses." 109 BMI disagreed. Because the consent decree did not prohibit fractional licensing, it was permitted.

The District Court overseeing BMI's consent decree agreed with BMI. Judge Stanton held that the "Consent Decree neither bars fractional licensing nor requires full-work licensing." 110 The Second Circuit, in reviewing the district court's interpretation of the consent decree de novo, affirmed. ${ }^{111}$ The DOJ's appeal began and ended with the language of the consent decree. Because the decree is silent on fractional licensing, BMI may (and perhaps must) offer them, as there was no evidence that a clear and unambiguous command of the decree would thereby be violated. ${ }^{112}$

Assistant Attorney General Delrahim cited this loss as clearly demonstrating the "challenge of regulating public performance rights through interpretations of decades-old consent decrees."113 But the loss stemmed from contract law, not competition policy. If the inclusion of fractional licensing increases the risks of anticompetitive behavior by ASCAP, BMI, or their members, then the Second Circuit specifically left open the opportunity to fix it: the DOJ could move to amend the decree or sue under the Sherman Act in a separate proceeding. ${ }^{114}$ Here again, amending the decree is far easier than challenging the restraint under the rule of reason standard.

\section{b. Replace the Consent Decrees with a Legislative Regulatory Framework}

If the DOJ no longer wants to enforce the ASCAP and BMI consent decrees, then an effective regulatory framework must be in place to ensure that BMI and ASCAP can

\footnotetext{
108 United States v. Broad. Music, Inc., 720 F. App'x 14, 18 (2d Cir. 2017).

$109 I d$. at 16.

110 United States v. Broad. Music, Inc., 207 F. Supp. 3d 374, 377 (S.D.N.Y. 2016).

111 United States v. BMI, 720 F. App'x at 18.

112 Id. at 16-17.

113 AAG June 13th Speech, supra note 6.

114 United States v. BMI, 720 F. App'x at 18.
} 
deliver the efficiencies of their collective licensing, while preventing them from engaging in monopolistic pricing or other anticompetitive behavior.

Congress could create the regulatory framework to replace the current role of the DOJ and federal courts. DOJ alluded to this in 2016.115 This has several potential benefits. A regulatory agency can be in a better position than an enforcement agency to hold hearings, collect data, and propose and enact regulatory changes.

But it is questionable whether the federal government needs yet another administrative agency, which raises its own costs and risks. Enforcing the ASCAP and BMI decrees is not a full-time job for the Antitrust Division. Nor is it a full-time job for the Media, Entertainment, and Professional Services Section within the Division that oversees the decrees. So it is questionable whether the regulatory framework warrants its own agency. Mission creep and regulatory capture could be two unintended consequences.

Having an existing administrative agency enforce the decrees' mandates could be an option. But as the Internet radio service Pandora argued to the DOJ in its recent review of the decrees,

these decrees are relevant and needed more than ever in light of increasing market concentration in the music publishing industry. They remain critical to constraining ASCAP's and BMI's overwhelming market power and the Department's continued involvement in this area is necessary. ${ }^{116}$

The expertise in harnessing the duopoly's pro-competitive efficiencies, while minimizing the anticompetitive risks, exists within a competition agency. Otherwise, the risk of anticompetitive regulations increases.

115 DOJ Closing Statement, supra note 18 (noting "the incongruity in the oversight over the licensing of performance rights and other copyrights in compositions and sound recordings," believing "that the protections provided by the consent decrees could be addressed through a legislative solution that brings performance rights licensing under a similar regulatory umbrella as other rights," and encouraging "the development of a comprehensive legislative solution that ensures a competitive marketplace and obviates the need for continued Division oversight of the PROs").

116 Pandora Comments, supra note 27. 


\section{c. Hybrid Approach: Consent Decree/Legislation}

Rather than an "either or" approach, where one group (Congress/another regulatory agency) or another group (the DOJ/courts) shoulder the weight in regulating ASCAP and BMI, it might make sense to shift some weight to Congress to enact regulatory reforms, while enabling DOJ to monitor the anticompetitive behavior it knows well, such as exclusionary, anticompetitive practices.

Toward this end is the Music Modernization Act, which is making its way through Congress. The House bill, for example, provides, among other things, for a Mechanical Licensing Collective, which would grant blanket mechanical licenses for interactive streaming or digital downloads of musical works. ${ }^{117}$

Some, including the DOJ, have advocated increasing transparency as to who owns which rights for particular songs. ${ }^{118}$ The National Religious Broadcasters Music License Committee noted in its recent comments to the DOJ of the "near-impossibility of identifying the potential licensors of any particular performance right":

Although the PROs offer on-line searches of their databases, they do not provide a reliable or effective means of identifying the content of each PRO's repertory. . . . All of the search tools limit searches to one work at a time, making searches for numerous works impractical.

As a result, it is effectively necessary for an entity engaging in substantial numbers of public performances, such as a radio broadcaster or a service making streamed performances, to obtain licenses from all three PROs. The major publishers, of course, understand the anticompetitive effects of the same behavior. Even where they seek to license their catalogs directly, they strategically withhold information about their content. ${ }^{119}$

\footnotetext{
117 Overview of the Music Modernization Act, https://lieu.house.gov/sites/lieu.house.gov/files/Overview\%20of\%20the\%20Music\%20Modernizati on\%20Act.pdf.

118 DOJ Closing Statement, supra note 18 (noting "the absence of a reliable source of data on song ownership to which music users could turn to identify whether they possess rights to perform a song or from whom they could seek a license").

119 National Religious Broadcasters' Comments, supra note 64, at 3.
} 
Currently some licensees obtain a blanket license from each PRO because they cannot easily determine who owns what rights for which works. ${ }^{120}$ Thus, to lower search and transaction costs, and increase the ability of licensees to negotiate directly with the rights holders, it makes sense to have a searchable, updated database to help licensees "more readily determine (i) who owns/controls the works they may wish to license and (ii) what works (and sound recordings in which they are embedded) they must avoid using to avoid infringement claims if they do not wish to accept the terms offered by a publisher/writer whose works are not available through a PRO (e.g., after a PRO 'withdrawal')."121

The proposed Music Modernization Act would provide a transparent and publicly accessible database housing song ownership information for licensing mechanical rights. As the report by the House Judiciary Committee noted:

The database that is required by this legislation will contain information such as the title of a work, its copyright owner(s) and shares thereof, contact information for the copyright owner(s), International Standard Recordings Codes (ISRC) and International Standard Work Codes (ISWC), relevant information for the sound recordings a work is embodied in, and any other information that the Register of Copyrights may prescribe by regulation. ${ }^{122}$

As the database contemplated in the proposed legislation appears to focus on data for licensing mechanical rights, it might be helpful to also increase transparency in the performance rights marketplace. Among other reasons, the Mechanical License Collective is statutorily barred from negotiating and licensing public performance rights and there will be no information about with which PROs a given work is affiliated in the proposed Music Modernization Act database. While the proposed Music Modernization Act database might present a potential model for improving transparency for performance rights licensing, it will not, by itself, resolve all the transparency issues.

\footnotetext{
120 Pandora Comments, supra note 27.

${ }^{121}$ Id.; see also National Religious Broadcasters' Comments, supra note 64.

122 H. Rept. 115-651 - Music Modernization Act, 115th Congress (2017-2018), https://www.congress.gov/115/crpt/hrpt651/CRPT-115hrpt651.pdf.
} 
Moreover, under the bill's "Wheel" Approach, a district judge in the Southern District of New York would be randomly assigned from the wheel of district judges for rate setting disputes. The "wheel" approach would enable BMI and ASCAP, as well as licensees, to go before any judge in the Southern District of New York on a rotating basis rather than being assigned to a single judge for the purpose of rate setting disputes. ${ }^{123}$

Consequently, the proposed Music Modernization Act, including a transparent and publicly accessible database housing song ownership information, can complement the protections afforded under the ASCAP and BMI consent decrees. The proposed legislation is not a substitute for the consent decrees as it does not address the potential anti-competitive issues involving ASCAP and BMI, such as monopoly pricing, exclusionary dealing, and discriminatory licensing. Instead, under this hybrid approach, legislation in increasing transparency can help lower search and transaction costs, and thereby along with the protections afforded in the ASCAP and BMI consent decrees can help spur competition.

\section{Conclusion}

Sometimes it is good to shake things up a bit. Sometimes change is good. But it may not be such a great idea to remove the legal scaffolding that supports an entire industry. The decrees have proven their worth in providing the pro-competitive efficiencies from ASCAP and BMI, while deterring some of the anticompetitive harms.

So, while one can appreciate the DOJ's desire to terminate obsolete decrees, it is important not to sweep with too broad a brush. Congress is far along in the process of creating a music licensing framework for the twenty-first century. The legislation balances the interests of composers, musicians, streaming services and others, and addresses long-standing disputes within the industry. Significantly, however, Congress has decided not to create a new performance licensing regime. Rather, it implicitly relies on the continuation of the ASCAP and BMI decrees and explicitly directs DOJ to think long and hard before seeking to do away with them. As the late

123 Overview of the Music Modernization Act, https://lieu.house.gov/sites/lieu.house.gov/files/Overview\%20of\%20the\%20Music\%20Modernizati on\%20Act.pdf. 
Allen P. Grunes \& Maurice E. Stucke

Potential Legal Issues in Terminating the ASCAP and BMI Decrees

July 31, 2018

B.B. King sang "Never make your move too soon." In clearing out old and obsolete decrees, the DOJ should heed this advice. 